\title{
ARTICLE
}

\section{A C-H bond activation-based catalytic approach to tetrasubstituted chiral allenes}

\author{
Shangze $\mathrm{Wu}^{1}$, Xin Huang ${ }^{1}$, Wangteng $\mathrm{Wu}^{1}$, Pengbin $\mathrm{Li}^{1}$, Chunling $\mathrm{Fu}^{1} \&$ Shengming $\mathrm{Ma}^{1}$
}

Enantioselective synthesis of fully substituted allenes has been a challenge due to the non-rigid nature of the axial chirality, which spreads over three carbon atoms. Here we show the commercially available simple Rh complex may catalyse the CMD (concerted metalation/deprotonation)-based reaction of the readily available arenes with sterically congested tertiary propargylic carbonates at ambient temperature affording fully substituted allenes. It is confirmed that the excellent designed regioselectivity for the $\mathrm{C}-\mathrm{C}$ triple bond insertion is induced by the coordination of the carbonyl group in the directing carbonate group as well as the steric effect of the tertiary O-linked carbon atom. When an optically active carbonate was used, surprisingly high efficiency of chirality transfer was realized, affording fully substituted allenes in excellent enantiomeric excess (ee).

\footnotetext{
${ }^{1}$ Laboratory of Molecular Recognition and Synthesis, Department of Chemistry, Zhejiang University, Hangzhou, Zhejiang 310027, China. Correspondence and requests for materials should be addressed to S.M. (email: masm@sioc.ac.cn).
} 
A llenes have been becoming more and more important due to their presence in nature and the recent demonstration of their great potentials in modern organic chemistry with very nice reactivities, which led to their versatile applications in the efficient total syntheses of some natural products and drugs ${ }^{1-4}$. Thus, the highly selective synthesis of allenes is of great importance ${ }^{5-10}$. On the basis of recent advancements, the enantioselective synthesis of 1,3-disubstituted or 1,1,3-trisubstituted allenes has been at least partially solved ${ }^{6}$, however, enantioselective synthesis of tetrasubstituted is still a challenge $^{6-10}$. Here we propose that the well-established CMD (concerted metalation/deprotonation) process of arenes ${ }^{11-16}$ would generate organometallic intermediates in situ, which would, in principle, react with 2-alkynylic derivatives with an appropriate leaving group to afford allenes via regioselectivityreversed insertion and thermodynamically non-favoured $\beta$-elimination (Fig. 1b). However, the challenge is the regioselectivity of the carbometalation of the $\mathrm{C}-\mathrm{C}$ triple bond with the in situ generated aryl metallic species ${ }^{17-22}$ since the reported insertion reaction with the $\mathrm{C}-\mathrm{C}$ triple bond in propargylic alcohols affording the $[4+2]$-products with the undesired regioselectivity ${ }^{18}$. To achieve our goal, we proposed to reverse the regioselectivity by installing a directing entity in the propargylic leaving group, thus avoiding the formation of undesired B-type insertion intermediate ${ }^{18}$. In addition, it should be noted that stereospecific $\beta$-elimination of the targeted intermediate A providing highly optically active allenes is challenging as the $\mathrm{Rh}$-catalysed reaction of stoichiometric amount each of aryl boronic acids and optically active propargylic acetates with forming allenes in an extremely low efficiency of chirality transfer due to the mixed syn- and antinon-stereospecific $\beta$-elimination ${ }^{23-25}$. In such a well-designed process, the oxidation state of the metal in the catalyst would remain the same, thus, making it catalytic in $[\mathrm{M}]$ and free of any oxidants for the regeneration of catalyst in many of $\mathrm{C}-\mathrm{H}$ functionalization reactions ${ }^{11-16}$.

Herein, we wish to report the realization of such a concept for the synthesis of tetrasubstituted allenes via the commercially available $\left[\mathrm{Cp}^{\star} \mathrm{RhCl}_{2}\right]_{2}$ catalysed coupling between readily available essential chemicals, that is, arenes and 2-alkynylic carbonates with a surprisingly high efficiency for point-to-axial chirality transfer. After careful studies, it is believed that the directing group and the steric effect of the tertiary 2-alkynylic carbonates are responsible for the reversed regioselectivity for the insertion of the $\mathrm{C}-\mathrm{C}$ triple bond.

\section{Results}

Identification of the leaving group. With the purpose of synthesizing the most challenging tetra-subtituted allenes, we first tried to identify a proper leaving group for the tertiary propargylic alcohol (Fig. 2): When $N$-methoxybenzamide 1a was reacted with tertiary propargylic methyl ether $\mathbf{2} \mathbf{a}_{\mathbf{1}}$ in a mixed solvent of $\mathrm{MeOH}$ and water (20/1) under the catalysis of $\left[\mathrm{Cp}^{\star} \mathrm{RhCl}_{2}\right]_{2}$ at room temperature, no allene was formed with 1a being recovered; when we introduced a phosphate as leaving group $\left(\mathbf{2 a}_{\mathbf{2}}\right)$, interestingly the expected tetrasubstituted allene 3aa was afforded in $8 \%$ NMR yield! ${ }^{18}$ When propargylic acetate $\mathbf{2} \mathbf{a}_{3}$ was used, the yield was improved to $46 \%$; with these results in hand, we envisioned to have a methoxy group to replace the methyl group in the acetyl unit to increase the electron density of the carbonyl oxygen, that is, carbonate: to our delight, the carbonate 2a was indeed the best and the yield was further improved to $76 \%$. After further optimization of the parameters of the reaction, the reaction of 1.2 equiv. 1a and $2 \mathbf{a}$ in a mixed solvent of $\mathrm{MeOH}$ and water (20/1) under the catalysis of $\left[\mathrm{Cp}^{\star} \mathrm{RhCl}_{2}\right]_{2}$ with $30 \mathrm{~mol} \% \mathrm{NaOAc}$ as base was chosen as the optimized reaction conditions for further study (for details of optimization, see Supplementary Table 1).

Substrate scope. The reaction proceeded well on a gram scale, affording 3 aa in $82 \%$ yield (Fig. 3). Having the optimized reaction conditions in hand, the generality of the reaction was then investigated. Electron-donating groups such as $t$-butyl and methoxy as well as electron-withdrawing groups such as $\mathrm{CF}_{3}$ and $\mathrm{F}$ in the aryl unit were all tolerated in the amides giving the corresponding fully substituted allenes in good to excellent yields (Fig. 3; 3aa, 3ba, 3ca, 3da, 3ea, 3bf and 3cf). It was noteworthy that when a meta-substituted $\mathbf{1 d}$ was used, the less hindered $\mathrm{C}-\mathrm{H}$ bond was exclusively functionalized and an $o$-fluorine atom did not hamper the reaction affording 3 ea in $79 \%$ yield (Fig. 3, 3da and 3ea). The $\mathrm{R}^{1}, \mathrm{R}^{2}$, and $\mathrm{R}^{3}$ groups in the 2 -alkynylic carbonate could be alkyl or aryl groups (Fig. 3; 3ac, 3ad, 3ae, 3af, 3ag, 3ah, $\mathbf{3 b f}$ and $3 \mathbf{c f}$ ). Substrates with sterically hindered $i$-Bu or $o$-tolyl groups also worked (Fig. 3, 3ac and 3ag).

Compatibility of functional groups. To show the robustness of our newly developed catalytic allene synthesis strategy, substrates with synthetically useful yet sensitive functional groups were explored without any protection: to our delight, $\mathrm{Cl}, \mathrm{Br}, \mathrm{CO}_{2} \mathrm{Me}$, $\mathrm{CN}$ and even unprotected free alcohol were all well tolerated,

a

CMD process of arenes and the subsequent reaction with a $\mathrm{C}-\mathrm{C}$ triple bond

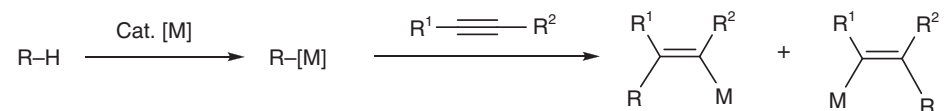

b

This work: $\mathrm{R}-\mathrm{M}$ formation via $\mathrm{CMD}$-regiospecific insertion affording $\mathbf{A}$-stereospecific $\beta$-elimination
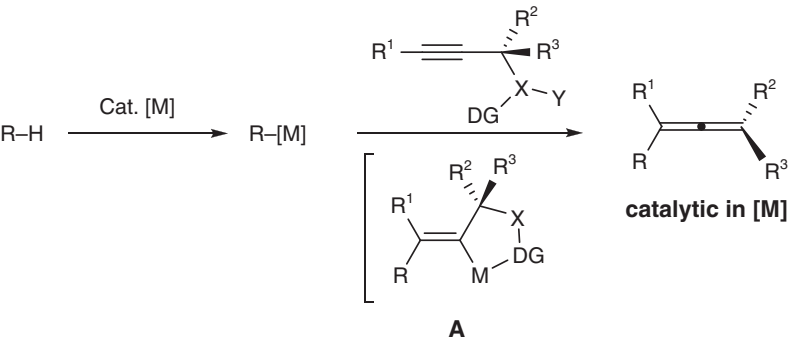

catalytic in $[\mathrm{M}]$

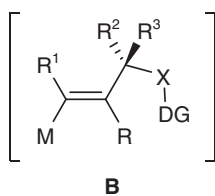

Figure 1 | Carbometallations of alkynes. (a) CMD-based reaction of R-H with alkynes. (b) This work: new concept and challenge for allene synthesis. 


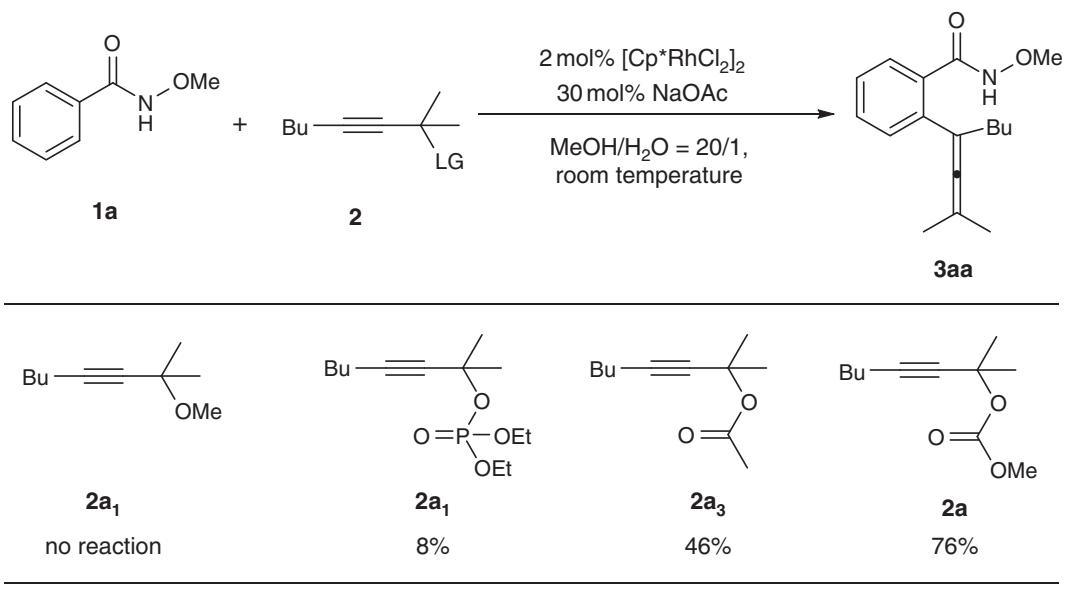

Yields were determined by ${ }^{1} \mathrm{H}$ NMR using $\mathrm{CH}_{2} \mathrm{Br}_{2}$ as internal standard.

Figure 2 | The effect of leaving groups. A carbonate was found to be the most efficient.

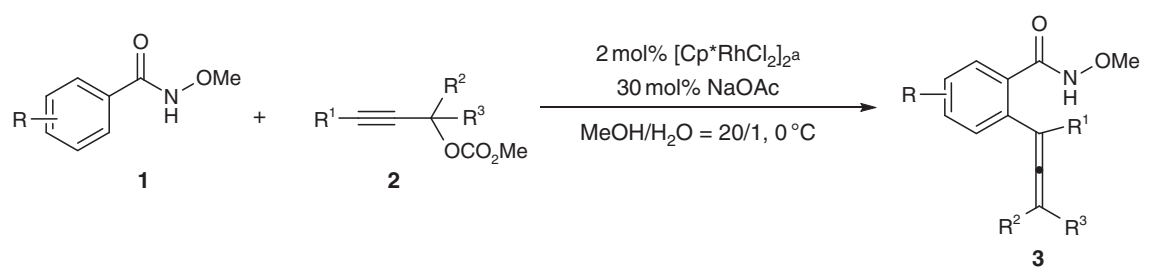

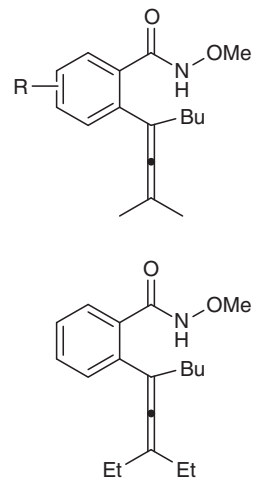

3ah, $77 \%$ 3aa, $\mathrm{R}=\mathrm{H}, 80 \%(82 \%)^{\mathrm{b}}$ 3ba, $\mathrm{R}=4-\mathrm{t}-\mathrm{Bu}, 73 \%$

3ca, $\mathrm{R}=4-\mathrm{OMe}, 74 \%{ }^{\mathrm{c}}$

3da, $\mathrm{R}=3-\mathrm{CF}_{3}, 83 \%$

3ea, $R=2-F, 79 \%$<smiles>CCC(C)=C=C(c1ccccc1)c1cc(C(C)(C)C)ccc1C(=O)NOC</smiles>

3bf, $73 \%{ }^{\mathrm{h}}$

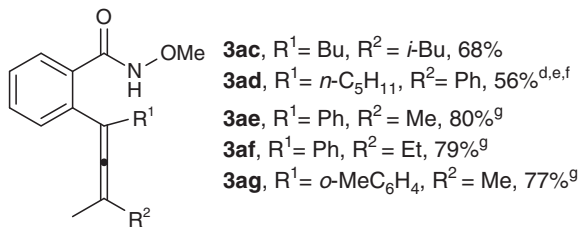<smiles>CCC(C)=CC=Cc1cc(OC)ccc1C(=O)NOC</smiles>

3cf, $74 \%{ }^{i}$

Figure 3 | Substrate scope. Electron-withdrawing and electron-donating as well as bulky groups were all tolerated. ${ }^{\mathrm{a}}$ The reaction was conducted with $1(1.2 \mathrm{mmol}), 2(1 \mathrm{mmol}),\left[\mathrm{Cp}{ }^{\star} \mathrm{RhCl}_{2}\right]_{2}(0.02 \mathrm{mmol}), \mathrm{NaOAc}(0.3 \mathrm{mmol}), \mathrm{MeOH}(6 \mathrm{ml})$, and $\mathrm{H}_{2} \mathrm{O}(0.3 \mathrm{ml})$ and monitored by TLC. beaction was conducted on $7 \mathrm{mmol}$ scale. ${ }^{C}$ Reaction was conducted at $-10^{\circ} \mathrm{C}, \mathbf{1 a}(1.3 \mathrm{mmol})$ and $\mathrm{NaOAc}(1 \mathrm{mmol})$ was used. ${ }^{\mathrm{d}}$ Reaction was conducted at room temperature. ${ }^{\mathrm{e}} \mathbf{1 a}(2 \mathrm{mmol}),\left[\mathrm{Cp}^{\star} \mathrm{RhCl}_{2}\right]_{2}(0.05 \mathrm{mmol})$ was used. ${ }^{\mathrm{f}}$ The acetate was used instead because of the unstability of the carbonate. ${ }^{\mathrm{g}} \mathbf{1} \mathbf{a}(1.5 \mathrm{mmol})$, $\left[\mathrm{Cp}^{\star} \mathrm{RhCl}_{2}\right]_{2}(0.04 \mathrm{mmol})$ was used. ${ }^{\mathrm{h}} \mathbf{b} \mathbf{b}(1.5 \mathrm{mmol}),\left[\mathrm{Cp}^{\star} \mathrm{RhCl}_{2}\right]_{2}(0.04 \mathrm{mmol})$ was used. ${ }^{1} \mathbf{1 c}(1.5 \mathrm{mmol}),\left[\mathrm{Cp}^{\star} \mathrm{RhCl}_{2}\right]_{2}(0.04 \mathrm{mmol})$ was used.

showing the broad synthetically attractive functional group compatibility (Fig. 4; 3fa, 3ff, 3ga, 3hi, 3ij and 3al). The structure of $3 \mathbf{f a}$ was further confirmed by X-ray diffraction study. (For details of the X-ray diffraction study of $\mathbf{3 f a}$, see Supplementary Dataset 1 and pages 96-97 in the Supplementary File.) Interestingly, even $\gamma$-(1-alkynyl)- $\gamma$-lactone $\mathbf{2 m}$ may be used to afford tetrasubstituted $\gamma$-allenoic acid 3am directly in an atom-economic way (Fig. 4; 3am).

Regioselectivity. The regioselectivity is an important issue when $>1 \mathrm{C}-\mathrm{H}$ bonds could be activated. When $\mathrm{N}$-methoxy-2naphthylcarboxylic amide $\mathbf{1 j}$ was used to react with $\mathbf{2 a}$, the less hindered $\mathrm{C}-\mathrm{H}$ bond was exclusively functionalized affording $\mathbf{3 j a}$ (Fig. 5, equation (a)). A heteroaryl $N$-methoxyamide $\mathbf{1 k}$ was also a suitable substrate and $\mathrm{C}-\mathrm{H}$ bond in the thiene moiety was exclusively functionalized giving $\mathbf{3 k a}$ in $81 \%$ yield (Fig. 5, equation (b); also see: Fig. 3; 3da).

Other directing groups. With this protocol in hand, we reasoned that such a concept should be working also with directing groups other than the $N$-methoxy amide. In fact, arenes $\mathbf{1 1}$ and $\mathbf{1} \mathbf{m}$ with directing groups of pyridine and pyrazole could also react with 2a forming tetrasubstituted allenes 3la and 3ma. Thus, such a protocol may be applied to other type of substrates with functionalizable $\mathrm{C}-\mathrm{H}$ bonds (Fig. 6).

Synthetic applications. The synthetic applications for the formed products were also conducted: 3la could react with an extra propargyl carbonate, affording bis-allene 5, which showed the possibility of a stepwise allenylation (Fig. 7, equation (a)). The 


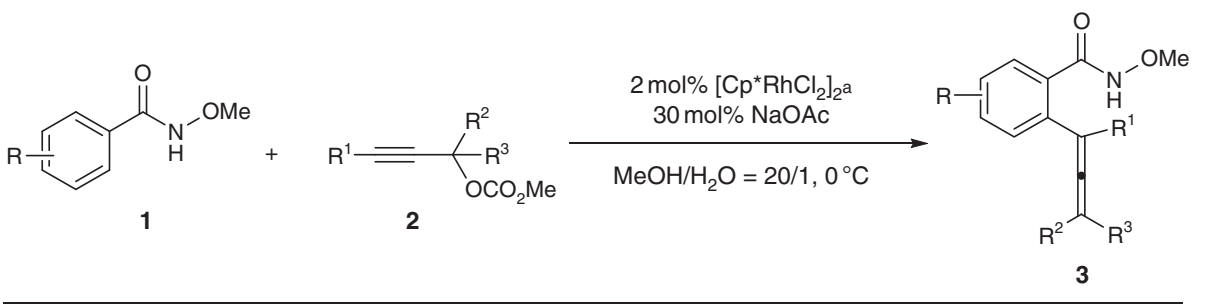<smiles>[R]C(C)=Cc1cc(Br)ccc1C(=O)NOC</smiles>

3fa, $R^{1}=\mathrm{Bu}, \mathrm{R}^{2}=\mathrm{Me}, 79 \%$ 3ff, $R^{1}=\mathrm{Ph}, \mathrm{R}^{2}=\mathrm{Et}, 79 \%$<smiles>CONC(=O)c1ccc(C#N)cc1C(=O)CO[In]</smiles>

3hi, $76 \%^{\mathrm{C}}$<smiles>CONC(=O)c1ccccc1C(Br)=CCC(=O)O</smiles><smiles>CC1(C#CBr)CCC(=O)O1</smiles>

$3 \mathbf{i j}, 58 \%$<smiles>CONC(=O)c1ccc(C(C)=O)cc1C(=Cc1ccccc1)C(C)C</smiles>

$3 g a, 76 \%$

3am, $50 \%$<smiles>CCC(C)=CC(=Cc1ccccc1C(=O)NOC)CCCCO</smiles>

3al, $70 \%$

Figure 4 | Functional group compatibility. Many synthetically useful yet sensitive functional groups survived without any protection. ${ }^{\mathrm{a}}$ The reaction was conducted with $\mathbf{1}(1.2 \mathrm{mmol}), \mathbf{2}(1 \mathrm{mmol}),\left[\mathrm{Cp}^{\star} \mathrm{RhCl}_{2}\right]_{2}(0.02 \mathrm{mmol}), \mathrm{NaOAc}(0.3 \mathrm{mmol}), \mathrm{MeOH}(6 \mathrm{ml})$ and $\mathrm{H}_{2} \mathrm{O}(0.3 \mathrm{ml})$ and monitored by TLC. ${ }^{b} \mathbf{1 f}(1.5 \mathrm{mmol}),\left[\mathrm{Cp}{ }^{\star} \mathrm{RhCl}_{2}\right]_{2}(0.04 \mathrm{mmol})$ was used. ${ }^{c}\left[\mathrm{Cp}^{\star} \mathrm{RhCl}_{2}\right]_{2}(0.04 \mathrm{mmol})$ was used.

a<smiles>CONC(=O)c1ccc2ccccc2c1</smiles>

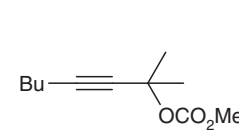

$2 a$

1.2 equiv.

b<smiles>CONC(=O)c1csc2ccccc12</smiles>

$1 \mathrm{k}$

1.2 equiv.

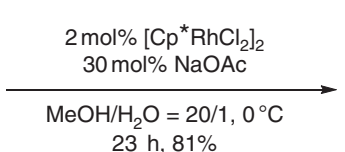

$\mathrm{H} / \mathrm{H}_{2} \mathrm{O}=20 / 1$
$23 \mathrm{~h}, 81 \%$

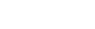<smiles>CONC(=O)c1cc2ccccc2cc1C=C(C)C</smiles>

$3 \mathbf{j a}$

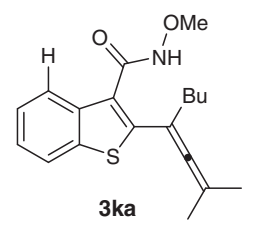

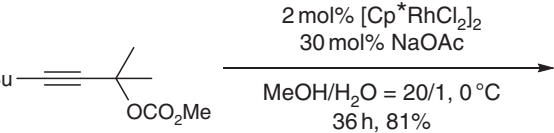

a

Figure 5 | Regioselectivity of the reaction. (a) The less hindered $\mathrm{C}-\mathrm{H}$ bond was exclusively functionalized. (b) The thiophene $\mathrm{C}-\mathrm{H}$ bond was exclusively functionalized.

$N$-methoxyamide moiety in 3aa could direct a well-known $[4+2]$ addition with 1,2-diphenylethyne giving isoquinolinone $\mathbf{6}$ with allene intact (Fig. 7, equation (b) $)^{18}$.

\section{Discussion}

In order to further study the mechanism, following experiments have been conducted. Firstly, $N$-methoxy-2-naphthamide $\mathbf{1 j}$ was 
a

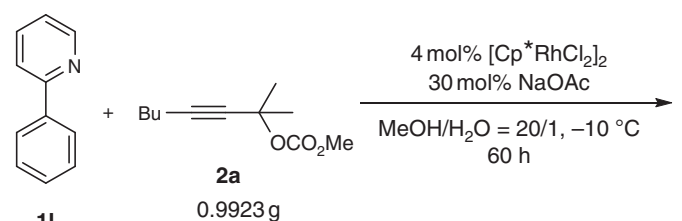

11

3 equiv., $2.3276 \mathrm{~g}$

$0.9923 \mathrm{~g}$

b<smiles>c1ccc(-n2cccn2)cc1</smiles><smiles>COC(C)(C)C#CC#CC(C)(C)OC</smiles>

2a

$1 \mathrm{~m}$<smiles>CC(C)=C=C(C)c1cccc(C(Br)=C=C(C)C)c1-c1ccccn1</smiles>

3la

$82 \%$

$$
3 \text { equiv. }
$$

Figure 6 | The scope of directing groups. Pyridine and pyrazole could also be suitable directing groups.

a<smiles>CC(C)=CC(Br)c1ccccc1-c1ccccn1</smiles>

3la
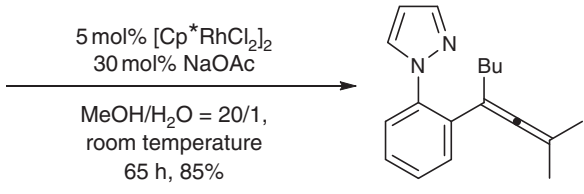

$3 \mathrm{ma}$

2 equiv.

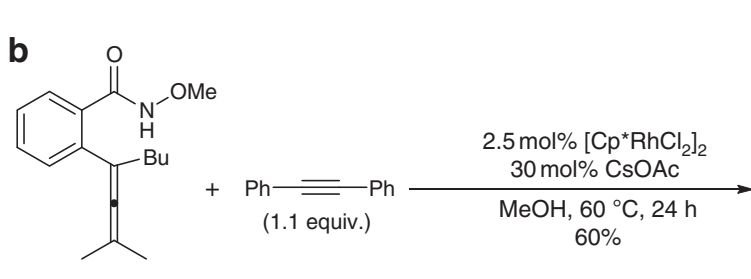

3aa

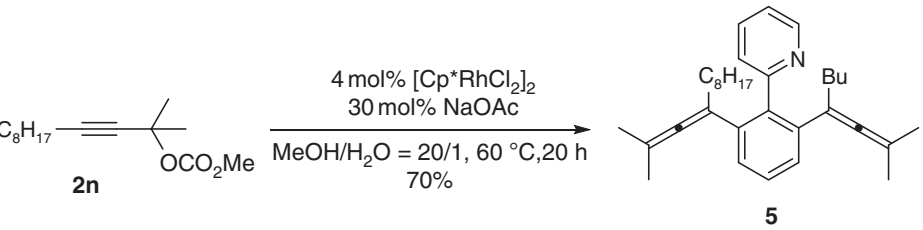<smiles>CC(C)=C=C(Br)c1cccc2c(-c3ccccc3)c(-c3ccccc3)[nH]c(=O)c12</smiles>

6

Figure 7 | The synthetic applications. (a) A stepwise allenylation. (b) A [4+2] addition affording isoquinolinone.<smiles>CONC(=O)c1ccc2ccccc2c1</smiles>

$1 \mathrm{j}$<smiles>COC(C#Cc1ccccc1)c1ccccc1</smiles>

20

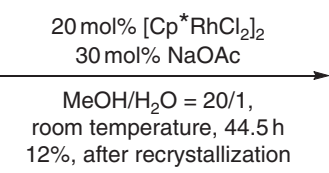
$12 \%$, after recrystallization<smiles>CONC(=O)c1cc2ccc(/C(=C/c3ccccc3)c3cc4ccccc4cc3C(=O)OC)cc2cc1/C(C(=O)c1ccccc1)=C(\c1ccccc1)C(OC(C)=O)c1ccccc1</smiles><smiles>COC(c1ccccc1)c1c(-c2ccccc2)[nH]c(=O)c2cc3ccccc3cc12</smiles>

7<smiles>C=IC</smiles><smiles>COC(=O)c1cc2ccccc2cc1/C(=C\c1ccccc1)c1ccccc1</smiles>

B-type

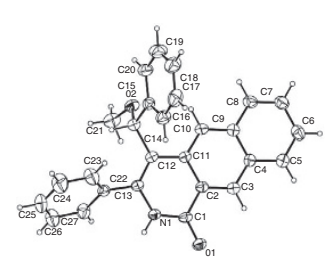

Figure 8 | Striking tertiary carbon atom effect. Secondary propargylic carbonate $\mathbf{2 0}$ only demonstrated the opposite regioselectivity.

treated with $20 \mathrm{~mol} \%$ of $\left[\mathrm{Cp}^{\star} \mathrm{RhCl}_{2}\right]_{2}$ to in situ generate the naphthyl $\mathrm{Rh}$ species, its reaction with secondary propargylic carbonate 20 demonstrated the opposite regioselectivity, leading to the undesired reported B-type insertion regioisomer exclusively ${ }^{18}$, finally yielding the $[4+2]$ product 7 observed by Fagnou, Glorius, Rovis, Cramer and other groups (Fig. 8; for details of the X-ray diffraction study of 7 , see Supplementary
Dataset 2 and page 108 in the Supplementary File) ${ }^{17-22}$ : the desired A-type insertion regioisomer, which would have led to the formation of allene via $\beta$-elimination, was not formed! Thus, we reasoned that there is a striking tertiary carbon atom effect here: in order to have the carbonyl group acts the directing group in this linear $\mathrm{C}-\mathrm{C}$ triple bond environment, the tertiary carbon atom in the carbonate may push the carbonyl group for its easier 
coordination with $\mathrm{Rh}$ while having a weaker interaction with the to-be-inserted C-C triple bond.

In the second place, to our delight, when chiral carbonate $\boldsymbol{S}-\mathbf{2 f}$ (98\% ee) was applied, axial chiral allenes were formed with an excellent ee $(98 \%$ ee) with a surprisingly high efficiency of chirality transfer (Fig. 9). The absolute configuration of chiral 3af was determined as $S$ by X-ray diffraction study and the absolute configurations of other chiral allenes $\boldsymbol{S}$-3bf, $\boldsymbol{S}$-3cf and $\boldsymbol{S}$-3fff were defined by analogy. (For details of the X-ray diffraction study of $S$-3af, see Supplementary Dataset 3 and page 110 in the Supplementary File.) These results further excluded the possibility of oxidative addition of propargylic carbonate with $\mathrm{Rh}$ to form allenyl rhodium intermediate (leading to racemization) $24,26,27$, which would react with arene via a CMD process followed by reductive elimination to afford the allene.

The kinetic isotope effect was measured by parallel experiments of $\mathbf{1 a}$ and $\mathbf{1 a}-\mathbf{D}_{\mathbf{5}}$ with $\mathbf{2 a}$. The kinetic isotope effect value of 2.1 demonstrated that $\mathrm{C}-\mathrm{H}$ activation should be the rate-determining step (Fig. 10a) ${ }^{28}$.

According to these results, a plausible mechanism has been proposed as shown in Fig. 10b. The first step of the ratedetermining CMD of arenes would form rhodabicyclic intermediate Int 1 (ref. 29), which is followed by coordination with the carbonyl oxygen of the carbonate forming Int 2 . Subsequent 'reversed' regiospecific insertion of the alkyne moiety ${ }^{18}$ directed by the carbonyl group in propargyl carbonate $\boldsymbol{S}$-2f afforded with the carbonyl oxygen-coordinated rhoda-tricyclic Int 3 (refs 11-14). The steric effect may set the carbonyl group for its better coordination with $\mathrm{Rh}$ and the subsequent defined coordination/insertion with $\mathrm{C}-\mathrm{C}$ triple bond leading to the formation of Int 3-type tricyclic intermediate, which directly underwent syn- $\beta$-oxygen elimination to form the final product $S$-3af and relieves the catalytically active $\mathrm{Rh}(\mathrm{III})$ species $^{30-37}$. It should be noted that usually anti- $\beta$-oxygen elimination was observed ${ }^{23-25}$. This syn- $\beta$-oxygen elimination explains the excellent efficiency for chirality transfer since it was reported that the Rh-catalysed reaction of optically active propargylic acetates with aryl boronic acids forming allenes in an extremely low efficiency of chirality transfer ${ }^{23-25}$.

In conclusion, a completely new protocol has been established for the efficient synthesis of allenes using the readily available arenes and 2-alkynylic carbonates as the starting materials at room temperature with very good yields. The reaction is compatible with ambient air, moisture and a broad array of synthetically useful functional groups such as $\mathrm{Cl}, \mathrm{Br}, \mathrm{CO}_{2} \mathrm{Me}, \mathrm{CN}$, free alcohol and even acid. The formed tetrasubstituted allenes could be transformed to isoquinolinone as while as bis-allene products. In fact, in some cases, very minor amount of cycloisomerisation products were observed in the NMR analysis of the crude products. Excellent selectivity for alkyne insertion must be induced by combination of carbonyl directing group as well as the steric effect of tertiary carbon centre. The surprisingly high efficiency of chirality transfer addresses the challenge for the synthesis of not-readily available highly optically active fully substituted allenes from a highly optically active carbonate. This protocol for the synthesis of allenes will trigger such reactions using other types of substrates with functionalizable $\mathrm{C}-\mathrm{H}$ bonds and propargylic alcohol derivatives, thus, will be of high interest in organic chemistry and related disciplines. Further studies in this area are being pursued in our laboratory.

\section{Methods}

Materials. $\left[\mathrm{Cp}^{*} \mathrm{RhCl}_{2}\right]_{2}$ was purchased from Strem Chemicals. $N$-methoxybenzamides ${ }^{22}$ and known propargylic carbonates ${ }^{38}$ were prepared according to the literature procedures. Other commercially available chemicals were purchased and used without additional purification unless noted otherwise.

General spectroscopic methods. ${ }^{1} \mathrm{H}$ NMR spectra were recorded on a Bruker-300 MHz spectrometer and ${ }^{13} \mathrm{C}$ NMR spectra were recorded at $75 \mathrm{MHz}$. All ${ }^{1} \mathrm{H}$ NMR experiments were measured with tetramethylsilane (0 p.p.m.) or the signal of residual $\mathrm{CHCl}_{3}$ (7.26 p.p.m.) in $\mathrm{CDCl}_{3}$ as the internal reference, ${ }^{13} \mathrm{C} \mathrm{NMR}$ experiments were measured in relative to the signal of $\mathrm{CDCl}_{3}$ (77.0 p.p.m.), and ${ }^{19} \mathrm{~F}$ NMR experiments were measured in relative to the signal of residual $\mathrm{CFCl}_{3}$ (0 p.p.m.) in $\mathrm{CDCl}_{3}$. Infrared spectra were recorded from this films of pure samples on sodium chloride plates for liquid or in the form of $\mathrm{KBr}$ discs for the solid samples. Mass and high-resolution mass spectrometry (HRMS) spectra were carried out in Electron Ionization (EI) mode. Thin-layer chromatography (TLC) was performed on pre-coated glass-back plates and visualized with ultraviolet light at $254 \mathrm{~nm}$. Flash column chromatography was performed on silica gel. ${ }^{1} \mathrm{H}$ NMR, ${ }^{13} \mathrm{C}$ NMR and High Performance Liquid Chromatography (HPLC) spectra (for chiral compounds) are supplied for all compounds: see Supplementary Figs 1-82. See Supplementary Methods for the characterization data of compounds not listed in this part.

Synthesis of 3aa. To a dried Schlenk tube equipped with a Teflon-coated magnetic stirring bar were added $N$-methoxybenzamide $1 \mathrm{a}(182.1 \mathrm{mg}, 1.2 \mathrm{mmol})$, $\left[\mathrm{Cp}^{*} \mathrm{RhCl}_{2}\right]_{2}(12.6 \mathrm{mg}, 0.02 \mathrm{mmol}), \mathrm{NaOAc}(24.3 \mathrm{mg}, 0.3 \mathrm{mmol})$, methyl (2methyloct-3-yn-2-yl) carbonate $2 \mathrm{a}(198.5 \mathrm{mg}, 1 \mathrm{mmol}), \mathrm{MeOH}(6 \mathrm{ml})$, and $\mathrm{H}_{2} \mathrm{O}$ $(0.3 \mathrm{ml})$ sequentially at room temperature. After being stirred for $19 \mathrm{~h} \mathrm{at} 0{ }^{\circ} \mathrm{C}$, the reaction was complete as monitored by TLC. Filtration through a short column of
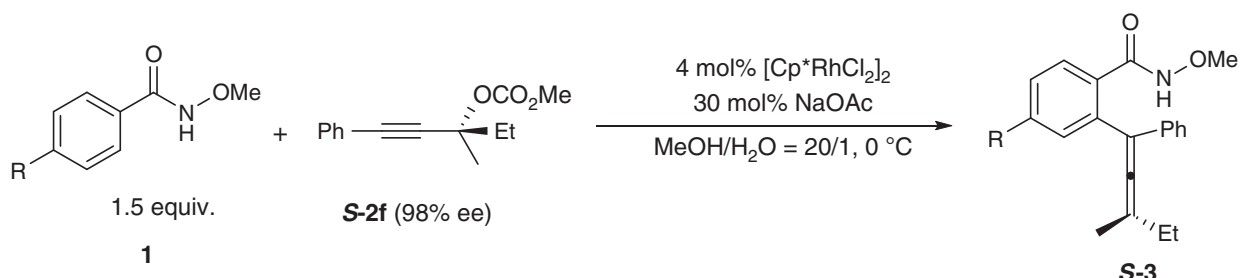

S-3

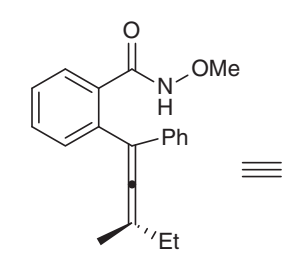

S-3af, $77 \%$, ee $=98 \%$

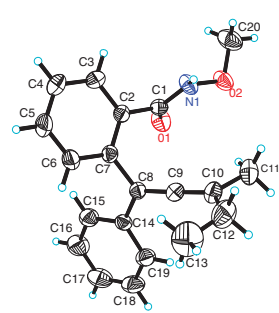<smiles>CCC(C)=C=C(c1ccccc1)c1cc(C(C)(C)C)ccc1C(=O)NOC</smiles><smiles>CCC(C)=C=C(c1ccccc1)c1cc(OC)ccc1C(=O)NOC</smiles>

S-3cf, $72 \%$, ee $=98 \%$<smiles>CCC(C)=C=C(c1ccccc1)c1ccc(Br)cc1C(=O)NOC</smiles>

S-3ff, $77 \%$, ee $=98 \%$

Figure 9 | Highly entioselective synthesis of tetra-substituted allenes by chirality transfer. Excellent efficiency of chirality transfer was found when using chiral carbonate $\mathbf{S}-\mathbf{2 f}$. The reaction was conducted with $\mathbf{1}(0.3 \mathrm{mmol}), \mathbf{2}(0.2 \mathrm{mmol}),\left[\mathrm{Cp}^{\star} \mathrm{RhCl}_{2}\right]_{2}(0.008 \mathrm{mmol}), \mathrm{NaOAc}(0.06 \mathrm{mmol}), \mathrm{MeOH}(1.2 \mathrm{ml})$, and $\mathrm{H}_{2} \mathrm{O}(0.06 \mathrm{ml})$ and monitored by TLC. The ees were determined by HPLC. 


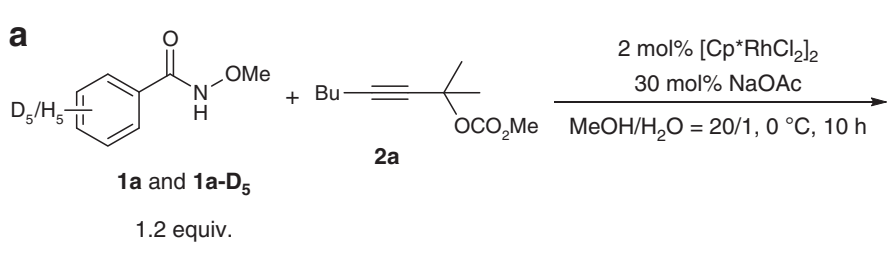

Parallel experment<smiles>CONC(=O)c1ccc([N+](=O)[O-])cc1C=C(C)C</smiles>

3aa and 3aa- $\mathrm{D}_{4}$

$\mathrm{KIE} \approx 2.1$

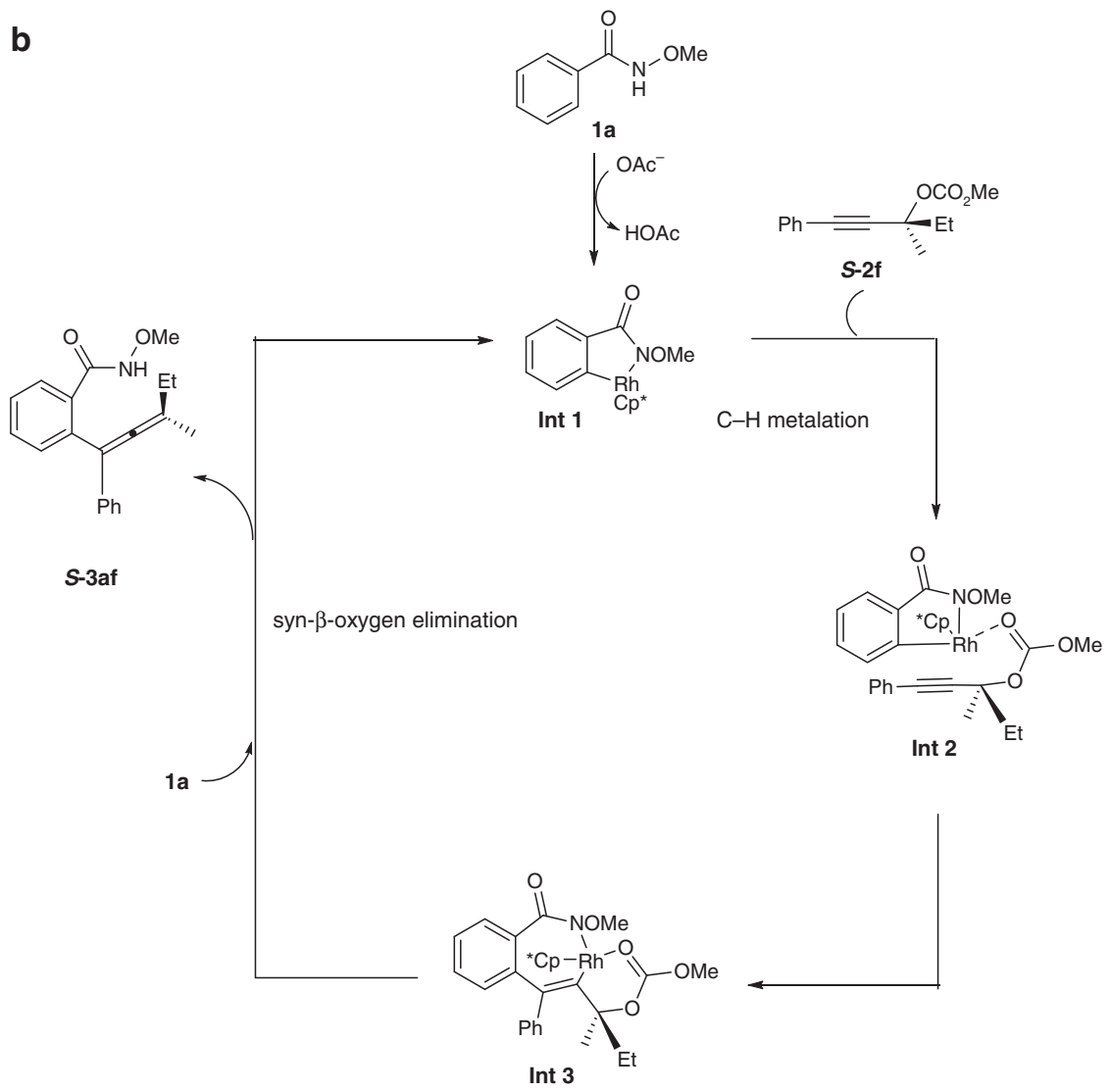

Figure 10 | Mechanistic issues (a) The kinetic isotope effect. A kinetic isotope effect value of 2.1 was measured. (b) Plausible mechanism. The carbonate carbonyl and tertiary carbon atom effect accounts for the reversed regioselectivity and the excellent efficiency of chirality was realized via syn- $\beta$-elimination.

silica gel (eluent: ethyl acetate $20 \mathrm{ml} \times 3$ ) and evaporation afforded the crude product, which was purified by flash column chromatography on silica gel (eluent: petroleum/ethyl acetate/dichloromethane $=10 / 1 / 0.1 /$ to $5 / 1 / 0.5)$ to afford 3 aa (218.6 mg, 80\%): solid; melting point (m.p.) $66.9-68.1^{\circ} \mathrm{C}$ (hexane/ethyl acetate); ${ }^{1} \mathrm{H}$ NMR $\left(300 \mathrm{MHz}, \mathrm{CDCl}_{3}\right) \delta 8.74$ (brs, $\left.1 \mathrm{H}, \mathrm{NH}\right), 7.58(\mathrm{~d}, J=7.2 \mathrm{~Hz}, 1 \mathrm{H}, \mathrm{Ar}-\mathrm{H})$, $7.39\left(\mathrm{td}, J_{1}=7.5 \mathrm{~Hz}, J_{2}=1.3 \mathrm{~Hz}, 1 \mathrm{H}, \mathrm{Ar}-\mathrm{H}\right), 7.32-7.21(\mathrm{~m}, 2 \mathrm{H}, \mathrm{Ar}-\mathrm{H}), 3.86(\mathrm{~s}, 3$ $\left.\mathrm{H}, \mathrm{OCH}_{3}\right), 2.29\left(\mathrm{t}, J=7.1 \mathrm{~Hz}, 2 \mathrm{H}, \mathrm{CH}_{2}\right), 1.76\left(\mathrm{~s}, 6 \mathrm{H}, 2 \times \mathrm{CH}_{3}\right), 1.49-1.27(\mathrm{~m}, 4 \mathrm{H}$, $\left.2 \times \mathrm{CH}_{2}\right), 0.89\left(\mathrm{t}, J=6.9 \mathrm{~Hz}, 3 \mathrm{H}, \mathrm{CH}_{3}\right) ;{ }^{13} \mathrm{C} \mathrm{NMR}\left(75 \mathrm{MHz} \mathrm{CDCl}_{3}\right) \delta 201.3,167.9$, $138.3,131.5,130.5,129.1,126.7,102.9,97.6,64.3,33.6,30.0,22.1,20.3,13.9$; IR (neat, $\mathrm{cm}^{-1}$ ) 3,188, 2,956, 2,931, 2,875, 2,859, 1,953, 1,659, 1,590, 1,495, 1,465, 1,440, 1,299, 1,156, 1,035; MS (EI, $70 \mathrm{eV}) \mathrm{m} / z(\%) 273\left(\mathrm{M}^{+}\right.$, 4.18), 242 (100); Anal. Calcd for $\mathrm{C}_{17} \mathrm{H}_{23} \mathrm{NO}_{2}$ : C 74.69, H 8.48, N 5.12. Found: C 74.89, H 8.62, N 4.89.

Synthesis of 5. To a dried Schlenk tube equipped with a Teflon-coated magnetic stirring bar were added $\left[\mathrm{Cp}^{*} \mathrm{RhCl}_{2}\right]_{2}(12.5 \mathrm{mg}, 0.02 \mathrm{mmol}), \mathrm{NaOAc}(12.8 \mathrm{mg}$, $0.15 \mathrm{mmol})$, 3la (277.5 mg, $1.0 \mathrm{mmol}), 2 \mathrm{n}$ (126.8 mg, $0.5 \mathrm{mmol}), \mathrm{MeOH}(3 \mathrm{ml})$, and $\mathrm{H}_{2} \mathrm{O}(0.15 \mathrm{ml})$ sequentially at room temperature. The Schlenk tube was then equipped with a condenser. After being stirred for $20 \mathrm{~h}$ at $60^{\circ} \mathrm{C}$, the reaction was complete as monitored by TLC (eluent: petroleum ether/ethyl acetate $=20 / 1$ ). Filtration through a short column of silica gel (eluent: ethyl acetate $20 \mathrm{ml} \times 3$ ) and evaporation afforded the crude product, which was purified by flash column chromatography on silica gel (eluent: hexane/ethyl acetate $=100 / 1$ ) to afford 5 (158.4 mg, 70\%): oil; ${ }^{1} \mathrm{H}$ NMR $\left(300 \mathrm{MHz}, \mathrm{CDCl}_{3}\right) \delta 8.61$ (d, $\left.J=4.2 \mathrm{~Hz}, 1 \mathrm{H}, \mathrm{Ar}-\mathrm{H}\right)$, $7.62\left(\mathrm{td}, J_{1}=7.8 \mathrm{~Hz}, J_{2}=1.8 \mathrm{~Hz}, 1 \mathrm{H}, \mathrm{Ar}-\mathrm{H}\right), 7.30-7.22(\mathrm{~m}, 2 \mathrm{H}, \mathrm{Ar}-\mathrm{H}), 7.21-7.11$ $(\mathrm{m}, 3 \mathrm{H}, \mathrm{Ar}-\mathrm{H}), 2.01-1.90\left(\mathrm{~m}, 4 \mathrm{H}, \mathrm{CH}_{2} \times 2\right), 1.39\left(\mathrm{~s}, 12 \mathrm{H}, \mathrm{CH}_{3} \times 4\right), 1.32-1.10$ $\left(\mathrm{m}, 16 \mathrm{H}, \mathrm{CH}_{2} \times 8\right), 0.87\left(\mathrm{t}, J=6.8 \mathrm{~Hz}, 3 \mathrm{H}, \mathrm{CH}_{3}\right), 0.80\left(\mathrm{t}, J=7.1 \mathrm{~Hz}, 3 \mathrm{H}, \mathrm{CH}_{3}\right)$ ${ }^{13} \mathrm{C} \mathrm{NMR}\left(75 \mathrm{MHz}, \mathrm{CDCl}_{3}\right) \delta 201.2,160.0,148.6,139.92,139.89,138.1,134.9$, $127.5,127.4,125.9,121.1,103.3,103.2,95.6,34.2,33.9,31.8,29.8,29.5,29.3,29.0$, 27.6, 22.6, 22.1, 20.4, 14.1, 14.0; IR (neat, $\mathrm{cm}^{-1}$ ) 3,059, 2,955, 2,926, 2,854, 1,962, $1,932,1,588,1,571,1,561,1,452,1,419,1,377,1,361,1,188,1,023$; MS (EI, $70 \mathrm{eV}$ ) $m / z(\%) 455\left(\mathrm{M}^{+}, 18.96\right), 84(100)$; HRMS Calcd for $\mathrm{C}_{33} \mathrm{H}_{45} \mathrm{~N}\left(\mathrm{M}^{+}\right): 455.3552$. Found: 455.3553

Synthesis of 6. To a dried Schlenk tube equipped with a Teflon-coated magnetic stirring bar were added $3 \mathrm{aa}(109.3 \mathrm{mg}, 0.4 \mathrm{mmol}), 1,2$-diphenylethyne $(78.6 \mathrm{mg}$, $0.44 \mathrm{mmol}),\left[\mathrm{Cp}^{\star} \mathrm{RhCl}_{2}\right]_{2}(6.2 \mathrm{mg}, 0.01 \mathrm{mmol}), \mathrm{CsOAc}(22.4 \mathrm{mg}, 0.12 \mathrm{mmol})$, and $\mathrm{MeOH}(2 \mathrm{ml})$ sequentially at room temperature. The Schlenk tube was then equipped with a condenser. After being stirred for $24 \mathrm{~h}$ at $60^{\circ} \mathrm{C}$, the reaction was complete as monitored by TLC (eluent: petroleum ether/ethyl acetate $=3 / 1$ ). Filtration through a short column of silica gel (eluent: (dichloromethane/ethyl acetate $=1 / 1)(20 \mathrm{ml} \times 3))$ and evaporation afforded the crude product, which was purified by flash column chromatography on silica gel (eluent: dichloromethane/ ethyl acetate $=20 / 1)$ to afford $6(101.1 \mathrm{mg}, 60 \%)$ : solid; m.p. $199.0-200.4^{\circ} \mathrm{C}$ (hexane/ethyl acetate); ${ }^{1} \mathrm{H} \mathrm{NMR}\left(300 \mathrm{MHz}, \mathrm{CDCl}_{3}\right) \delta 9.02(\mathrm{~s}, 1 \mathrm{H}, \mathrm{Ar}-\mathrm{H}), 7.44$ $(\mathrm{t}, J=7.8 \mathrm{~Hz}, 1 \mathrm{H}, \mathrm{Ar}-\mathrm{H}), 7.34-7.10(\mathrm{~m}, 12 \mathrm{H}, \mathrm{Ar}-\mathrm{H}), 2.33(\mathrm{t}, J=7.1 \mathrm{~Hz}, 2 \mathrm{H}$, $\left.\mathrm{CH}_{2}\right), 1.76\left(\mathrm{~s}, 6 \mathrm{H}, \mathrm{CH}_{3} \times 2\right), 1.53-1.29\left(\mathrm{~m}, 4 \mathrm{H}, \mathrm{CH}_{2} \times 2\right), 0.90(\mathrm{t}, J=7.1 \mathrm{~Hz}, 3 \mathrm{H}$, $\left.\mathrm{CH}_{3}\right) ;{ }^{13} \mathrm{C} \mathrm{NMR}\left(75 \mathrm{MHz}, \mathrm{CDCl}_{3}\right) \delta 199.0,161.6,142.7,140.2,137.2,136.4,135.1$, $131.9,131.7,129.8,129.0,128.5,128.3,127.1,124.9,122.5,116.8,106.9,95.6,34.7$ $30.5,22.5,20.9,14.2$; IR (neat, $\mathrm{cm}^{-1}$ ) 3,453, 3,165, 3,027, 2,947, 2,929, 2,869, 2,849, $1,947,1,642,1,596,1,584,1,486,1,462,1,441,1,311,1,144$; MS (EI, $70 \mathrm{eV}) \mathrm{m} / z(\%)$ 
$419\left(\mathrm{M}^{+}, 31.3\right), 376(100)$; HRMS Calcd for $\mathrm{C}_{30} \mathrm{H}_{29} \mathrm{NO}\left(\mathrm{M}^{+}\right)$: 419.2249. Found: 419.2247. Anal. Calcd for $\mathrm{C}_{30} \mathrm{H}_{29} \mathrm{NO}$ : C 85.88, H 6.97, N 3.34. Found: C 84.90, H 6.96, N 3.31 .

Synthesis of 7. Following procedure for the synthesis of $\mathbf{3 a a}$, the reaction of $\mathbf{1 j}$ (303.1 mg, $1.5 \mathrm{mmol}$ ), $\left[\mathrm{Cp}^{*} \mathrm{RhCl}_{2}\right]_{2}$ (185.5 mg, $0.3 \mathrm{mmol}$ ), $\mathrm{NaOAc}(36.9 \mathrm{mg}$, $0.45 \mathrm{mmol}), 2 \mathrm{o}(400.1 \mathrm{mg}, 1.5 \mathrm{mmol}), \mathrm{MeOH}(9 \mathrm{ml})$, and $\mathrm{H}_{2} \mathrm{O}(0.45 \mathrm{ml})$ at room temperature afforded impure 7 with impurities $(136.8 \mathrm{mg}$ ) (eluent: Hexane/ethyl acetate/dichloromethane $=10 / 1 / 0.2$ to $8 / 1 / 0.5$ ), which was further purified by recrystallization (hexane/THF) afford pure 7 (69.7 mg, 12\%): solid; m.p. $117.5-119.0^{\circ} \mathrm{C}$ (hexane/THF); ${ }^{1} \mathrm{H}$ NMR $\left(300 \mathrm{MHz}, \mathrm{CDCl}_{3}\right) \delta 9.02(\mathrm{~s}, 1 \mathrm{H}, \mathrm{Ar}-\mathrm{H})$, 8.91 (bs, $1 \mathrm{H}, \mathrm{NH}), 8.32$ (s, $1 \mathrm{H}, \mathrm{Ar}-\mathrm{H}), 8.06-7.94(\mathrm{~m}, 1 \mathrm{H}, \mathrm{Ar}-\mathrm{H}), 7.75-7.66$ (m, $1 \mathrm{H}, \mathrm{Ar}-\mathrm{H}), 7.55-7.40$ (m, $8 \mathrm{H}, \mathrm{Ar}-\mathrm{H}), 7.36-7.17$ (m, $4 \mathrm{H}, \mathrm{Ar}-\mathrm{H}), 5.57$ (s, $1 \mathrm{H}$, $\mathrm{CH}), 3.31\left(\mathrm{~s}, 3 \mathrm{H}, \mathrm{CH}_{3}\right) ;{ }^{13} \mathrm{C} \mathrm{NMR}\left(75 \mathrm{MHz}, \mathrm{CDCl}_{3}\right) \delta 163.2,141.6,139.4,135.1$, 134.8, 131.2, 131.1, 129.6, 129.04, 128.97, 128.81, 128.77, 128.5, 128.3, 127.8, 127.1, 126.6, 126.2, 124.5, 111.1, 80.3, 56.5; IR (neat, $\mathrm{cm}^{-1}$ ) 3,181, 3,057, 3,027, 2,927, $2,890,2,819,1,659,1,625,1,600,1,493,1,448,1,355,1,312,1,089,1022$; MS (EI, $70 \mathrm{eV}) \mathrm{m} / \mathrm{z}(\%) 392\left(\mathrm{M}^{+}+1,30.89\right), 391\left(\mathrm{M}^{+}, 100\right)$; HRMS Calcd for $\mathrm{C}_{27} \mathrm{H}_{21} \mathrm{NO}_{2}\left(\mathrm{M}^{+}\right): 391.1572$. Found: 391.1571 .

Synthesis of S-3af. Following procedure for the synthesis of 3aa, the reaction of $1 \mathrm{a}(45.6 \mathrm{mg}, 0.3 \mathrm{mmol}),\left[\mathrm{Cp}^{\star} \mathrm{RhCl}_{2}\right]_{2}(4.8 \mathrm{mg}, 0.008 \mathrm{mmol}), \mathrm{NaOAc}(5.3 \mathrm{mg}$, $0.06 \mathrm{mmol}), S$-2f $(98 \%$ ee, $45.9 \mathrm{mg}, 0.2 \mathrm{mmol}), \mathrm{MeOH}(1.2 \mathrm{ml})$, and $\mathrm{H}_{2} \mathrm{O}(0.06 \mathrm{ml})$ at $0{ }^{\circ} \mathrm{C}$ afforded $S$-3af $(46.6 \mathrm{mg}, 77 \%)$ (eluent: petroleum/ethyl acetate/ dichloromethane $=5 / 1 / 0.5$ ): $98 \%$ ee (HPLC conditions: Chiralcel AD-H column, hexane $/ i-\mathrm{PrOH}=10 / 1,1.0 \mathrm{ml} \mathrm{min}^{-1}, \lambda=207 \mathrm{~nm}, t_{\mathrm{R}(\text { minor })}=21.9 \mathrm{~min}$ $\left.t_{\mathrm{R}(\text { major })}=24.5 \mathrm{~min}\right)$; solid; m.p. $99.9-101.1{ }^{\circ} \mathrm{C}$ (hexane/ethyl acetate); ${ }^{1} \mathrm{H}$ NMR $\left(300 \mathrm{MHz}, \mathrm{CDCl}_{3}\right) \delta 8.66(\mathrm{~s}, 1 \mathrm{H}, \mathrm{NH}), 7.78(\mathrm{~d}, J=7.5 \mathrm{~Hz}, 1 \mathrm{H}, \mathrm{Ar}-\mathrm{H}), 7.53-7.14$ $(\mathrm{m}, 8 \mathrm{H}, \mathrm{Ar}-\mathrm{H}), 3.45\left(\mathrm{~s}, 3 \mathrm{H}, \mathrm{OCH}_{3}\right), 2.27-2.06\left(\mathrm{~m}, 2 \mathrm{H}, \mathrm{CH}_{2}\right), 1.90\left(\mathrm{~s}, 3 \mathrm{H}, \mathrm{CH}_{3}\right)$, $1.13\left(\mathrm{t}, J=7.4 \mathrm{~Hz}, 3 \mathrm{H}, \mathrm{CH}_{3}\right) ;{ }^{13} \mathrm{C}$ NMR $\left(75 \mathrm{MHz}, \mathrm{CDCl}_{3}\right) \delta 202.0,166.6,137.2$, $135.6,132.5,131.20,131.18,129.6,128.6,127.9,127.1,126.5,107.5,106.5,63.9$, 27.4, 18.7, 12.3; IR (neat, $\mathrm{cm}^{-1}$ ) 3,199, 3,058, 3,018, 2,966, 2,932, 1,947, 1,659, $1,595,1,491,1,456,1,439,1,310,1,159,1,031$; MS (EI, $70 \mathrm{eV}) \mathrm{m} / \mathrm{z}$ (\%) 307 $\left(\mathrm{M}^{+}, 1.69\right), 246$ (100); Anal. Calcd for $\mathrm{C}_{20} \mathrm{H}_{21} \mathrm{NO}_{2}: \mathrm{C} 78.15, \mathrm{H}$ 6.89, $\mathrm{N}$ 4.56. Found: C 77.98, H $6.88, \mathrm{~N} 4.34$

\section{References}

1. Ma, S. Some typical advances in the synthetic applications of allenes. Chem. Rev. 105, 2829-2871 (2005).

2. Alcaide, B. \& Almendros, P. 'Progress in allene chemistry' Special issue, Eds. Chem. Soc. Rev. 43, 2879-3206 (2014).

3. Hoffmann-Röder, A. \& Krause, N. Synthesis and properties of allenic natural products and pharmaceuticals. Angew. Chem. Int. Ed. 43, 1196-1216 (2004).

4. Yu, S. \& Ma, S. Allenes in catalytic asymmetric synthesis and natural product syntheses. Angew. Chem., Int. Ed. 51, 3074-3112 (2012)

5. Yu, S. \& Ma, S. How easy are the syntheses of allenes? Chem. Commun. 47, 5384-5418 (2011)

6. Ye, J. \& Ma, S. Conquering three-carbon axial chirality of allenes. Org. Chem. Front. 1, 1210-1224 (2014)

7. Miura, T., Shimada, M., Ku, S.-Y., Tamai, T. \& Murakami, M. Stereoselective synthesis of a-allenols by rhodium-catalyzed reaction of alkynyl oxiranes with arylboronic acids. Angew. Chem. Int. Ed. 46, 7101-7103 (2007).

8. Hayashi, S., Hirano, K., Yorimitsu, H. \& Oshima, K. Synthesis of arylallenes by palladium-catalyzed retro-propargylation of homopropargyl alcohols. J. Am. Chem. Soc. 130, 5048-5049 (2008).

9. Shu, W., Jia, G. \& Ma, S. Palladium-catalyzed regioselective cyclopropanating allenylation of (2,3-butadienyl)malonates with propargylic carbonates and their application to synthesize cyclopentenones. Org. Lett. 11, 117-120 (2009).

10. Hashimoto, T., Sakata, K., Tamakuni, F., Dutton, M. J. \& Maruoka, K. Phase-transfer-catalysed asymmetric synthesis of tetrasubstituted allenes. Nat. Chem. 5, 240-244 (2013).

11. Satoh, T. \& Miura, M. Oxidative coupling of aromatic substrates with alkynes and alkenes under rhodium catalysis. Chem. Eur. J. 16, 11212-11222 (2010).

12. Colby, D. A., Bergman, R. G. \& Ellman, J. A. Rhodium-catalyzed C-C bond formation via heteroatom-directed C-H bond activation. Chem. Rev. 110, 624-655 (2010).

13. Song, G., Wang, F. \& Li, X. C-C, C-O and C-N bond formation via rhodium(III)-catalyzed oxidative C-H activation. Chem. Soc. Rev. 41, 3651-3678 (2012).

14. Kuhl, N., Schröder, N. \& Glorius, F. Formal $\mathrm{S}_{\mathrm{N}}$-type reactions in rhodium (III)-catalyzed C-H Bond activation. Adv. Synth. Catal. 356, 1443-1460 (2014).

15. Ackermann, L. Carboxylate-assisted transition-metal-catalyzed C-H bond functionalizations: mechanism and scope. Chem. Rev. 111, 1315-1345 (2011).

16. Engle, K. M., Mei, T.-S., Wasa, M. \& Yu, J.-Q. Weak coordination as a powerful means for developing broadly useful $\mathrm{C}-\mathrm{H}$ functionalization reactions. Acc. Chem. Res. 45, 788-802 (2011).

17. Ackermann, L. \& Fenner, S. Ruthenium-catalyzed C-H/N-O bond functionalization: green isoquinolone syntheses in water. Org. Lett. 13, 6548-6551 (2011).
18. Guimond, N., Gouliaras, C. \& Fagnou, K. Rhodium(III)-catalyzed isoquinolone synthesis: the $\mathrm{N}-\mathrm{O}$ bond as a handle for $\mathrm{C}-\mathrm{N}$ bond formation and catalyst turnover. J. Am. Chem. Soc. 132, 6908-6909 (2010).

19. Schipper, D. J., Hutchinson, M. \& Fagnou, K. Rhodium(III)-catalyzed intermolecular hydroarylation of alkynes. J. Am. Chem. Soc. 132, 6910-6911 (2010).

20. Rakshit, S., Patureau, F. W. \& Glorius, F. Pyrrole synthesis via allylic $\mathrm{sp}^{3} \mathrm{C}-\mathrm{H}$ activation of enamines followed by intermolecular coupling with unactivated alkynes. J. Am. Chem. Soc. 132, 9585-9587 (2010).

21. Hyster, T. K. \& Rovis, T. Rhodium-catalyzed oxidative cycloaddition of benzamides and alkynes via C-H/N-H activation. J. Am. Chem. Soc. 132, 10565-10569 (2010).

22. Pham, M. V., Ye, B. \& Cramer, N. Access to sultams by rhodium(III)-catalyzed directed C-H activation. Angew. Chem. Int. Ed. 51, 10610-10614 (2012).

23. Murakami, M. \& Igawa, H. A study of the stereochemical course of $\beta$-oxygen elimination with a rhodium(I) complex. Helv. Chim. Acta 85, 4182-4188 (2002).

24. Xu, L., Zhu, Q., Huang, G., Cheng, B. \& Xia, Y. Computational elucidation of the internal oxidant-controlled reaction pathways in $\mathrm{Rh}(\mathrm{III})$-catalyzed aromatic C-H functionalization. J. Org. Chem. 77, 3017-3024 (2012).

25. Alexakis, A., Marek, I., Mangeney, P. \& Normant, J. F. Mechanistic aspects on the formation of chiral allenes from propargylic ethers and organocopper reagents. J. Am. Chem. Soc. 112, 8042-8047 (1990).

26. Xie, F., Qi, Z., Yu, S. \& Li, X. Rh(III)- and Ir(III)-catalyzed C - H alkynylation of arenes under chelation assistance. J. Am. Chem. Soc. 136, 4780-4787 (2014)

27. Schröder, N., Wencel-Delord, J. \& Glorius, F. High-yielding, versatile, and practical $\left[\mathrm{Rh}(\mathrm{III}) \mathrm{Cp}^{*}\right]$-catalyzed ortho bromination and iodination of arenes. J. Am. Chem. Soc 134, 8298-8301 (2012).

28. Simmons, E. M. \& Hartwig, J. F. On the interpretation of deuterium kinetic isotope effects in $\mathrm{C}-\mathrm{H}$ bond functionalizations by transition-metal complexes Angew. Chem. Int. Ed. 51, 3066-3072 (2012).

29. Wu, S., Zeng, R., Fu, C., Yu, Y., Zhang, X. \& Ma, S. Rhodium-catalyzed C-H functionalization-based approach to eight-membered lactams. Chem. Sci 6, 2275-2285 (2015).

30. Ma, S. \& Yu, S. Palladium-catalyzed functionalization of indoles with 2-acetoxymethyl substituted electron-deficient alkenes. Tetrahedron Lett. 45, 8419-8422 (2004).

31. Oi, S., Tanaka, Y. \& Inoue, Y. Ortho-selective allylation of 2-pyridylarenes with allyl acetates catalyzed by ruthenium complexes. Organometallics $\mathbf{2 5}$, 4773-4778 (2006).

32. Kuninobu, Y., Ohtan, K. \& Takai, K. Rhenium-catalyzed allylation of C-H bonds of benzoic and acrylic acids. Chem. Commun. 47, 10791-10793 (2011).

33. Yao, T., Hirano, K., Satoh, T. \& Miura, M. Stereospecific copper-catalyzed C-H allylation of electron-deficient arenes with allyl phosphates. Angew. Chem. Int. Ed. 50, 2990-2994 (2011).

34. Makida, Y., Ohmiya, H. \& Sawamura, M. Regio- and stereocontrolled introduction of secondary alkyl groups to electron-deficient arenes through copper-catalyzed allylic alkylation. Angew. Chem. Int. Ed. 51, 4122-4127 (2012).

35. Fan, S., Chen, F. \& Zhang, X. Direct palladium-catalyzed intermolecular allylation of highly electron-deficient polyfluoroarenes. Angew. Chem. Int. Ed. 50, 5918-5923 (2011).

36. Yu, Y.-B., Fan, S. \& Zhang, X. Copper- and phosphine-ligand-free palladiumcatalyzed direct allylation of electron-deficient polyfluoroarenes with allylic chlorides. Chem. Eur. J 18, 14643-14648 (2012).

37. Wang, H., Schröder, N. \& Glorius, F. Mild rhodium(III)-catalyzed direct C-H allylation of arenes with allyl carbonates. Angew. Chem. Int. Ed. 52, 5386-5389 (2013).

38. Shu, W. Studies on Palladium-Catalyzed Two- or Three-Component Cyclization Reactions Involving Allenes. $\mathrm{PhD}$ thesis, Shanghai Institute of Organic Chemistry, China (2010).

\section{Acknowledgements}

Financial support is acknowledged from National Basic Research Program (2015CB856600) of China. S.M. is a Qiu Shi Adjunct Professor at Zhejiang University. We thank Mr. Weilong Lin in this group for reproducing the results for synthesis of 3ah, 3ga and $S$-3cf.

\section{Author contributions}

S.M. directed the research and developed the concept of the reaction with S.W. S.W. performed the experiments and data analysis. X.H. performed some experiments. W.W. and P.L. contributed in helping collecting some experimental data. S.W., C.F. and S.M. checked the experimental data with the help of X.H. The paper was written by S.W. and S.M. with assistance from the other authors.

\section{Additional information}

Supplementary Information accompanies this paper at http://www.nature.com/ naturecommunications

Competing financial interests: The authors declare no competing financial interests. 
Reprints and permission information is available online at http://npg.nature.com/ reprintsandpermissions/

How to cite this article: Shangze, W. et al. A C-H bond activation-based catalytic approach to tetrasubstituted chiral allenes. Nat. Commun. 6:7946 doi: 10.1038/ ncomms8946 (2015). (c) (i) This work is licensed under a Creative Commons Attribution 4.0 International License. The images or other third party material in this article are included in the article's Creative Commons license, unless indicated otherwise in the credit line; if the material is not included under the Creative Commons license, users will need to obtain permission from the license holder to reproduce the material. To view a copy of this license, visit http://creativecommons.org/licenses/by/4.0/ 